\title{
Impacts of new particle formation on aerosol cloud condensation nuclei (CCN) activity in Shanghai: case study
}

\author{
C. Leng ${ }^{1}$, Q. Zhang ${ }^{1}$, J. Tao ${ }^{2}$, H. Zhang ${ }^{3}$, D. Zhang ${ }^{1}$, C. Xu ${ }^{1}$, X. Li ${ }^{1}$, L. Kong ${ }^{1}$, T. Cheng ${ }^{1}$, R. Zhang ${ }^{4}$, X. Yang ${ }^{1}$, \\ J. Chen ${ }^{1}$, L. Qiao ${ }^{5}$, S. Lou ${ }^{5}$, H. Wang ${ }^{5}$, and C. Chen ${ }^{5}$ \\ ${ }^{1}$ Shanghai Key Laboratory of Atmospheric Particle Pollution and Prevention (LAP ${ }^{3}$ ), Fudan-Tyndall Centre, \\ Department of environmental science and engineering, Fudan University, Shanghai 200433, China \\ ${ }^{2}$ South China Institute of Environmental Sciences, Ministry of Environmental Protection, \\ Guangzhou 510655, China \\ ${ }^{3}$ Atmospheric Environment Institute, Chinese Research Academy of Environmental Sciences, \\ Beijing 100012, China \\ ${ }^{4}$ Key Laboratory of Region Climate-Environment Research for Temperate East Asia, \\ Institute of Atmospheric Physics, Chinese Academy of Sciences, Beijing 100029, China \\ ${ }^{5}$ State Environmental Protection Key Laboratory of the Cause and Prevention of Urban Pollution Complex, \\ Shanghai Academy of Environmental Sciences, Shanghai 200233, China
}

Correspondence to: T. Cheng (ttcheng@ fudan.edu.cn) and J. Chen (jmchen@fudan.edu.cn)

Received: 8 June 2014 - Published in Atmos. Chem. Phys. Discuss.: 14 July 2014

Revised: 16 September 2014 - Accepted: 17 September 2014 - Published: 29 October 2014

\begin{abstract}
New particle formation (NPF) events and their impacts on cloud condensation nuclei $(\mathrm{CCN})$ were investigated using continuous measurements collected in urban Shanghai from 1 to 30 April 2012. During the campaign, NPF occurred in 8 out of the 30 days and enhanced CCN number concentration $\left(N_{\mathrm{CCN}}\right)$ by a factor of $1.2-1.8$, depending on supersaturation (SS). The NPF event on 3 April 2012 was chosen as an example to investigate the NPF influence on $\mathrm{CCN}$ activity. In this NPF event, secondary aerosols were produced continuously and increased $\mathrm{PM}_{2.5}$ mass concentration at a rate of $4.33 \mu \mathrm{g} \mathrm{cm}^{-3} \mathrm{~h}^{-1}$, and the growth rate (GR) and formation rate (FR) were on average $5 \mathrm{~nm} \mathrm{~h}^{-1}$ and $0.36 \mathrm{~cm}^{-3} \mathrm{~s}^{-1}$, respectively. The newly formed particles grew quickly from nucleation mode $(10-20 \mathrm{~nm})$ into $\mathrm{CCN}$ size range. $N_{\mathrm{CCN}}$ increased rapidly at SS of $0.4-1.0 \%$ but weakly at SS of $0.2 \%$. Correspondingly, aerosol CCN activities (fractions of activated aerosol particles in total aerosols, $N_{\mathrm{CCN}} / N_{\mathrm{CN}}$ ) were significantly enhanced from $0.24-0.60$ to $0.30-0.91$ at SS of $0.2-1.0 \%$ due to the NPF. On the basis of the $\kappa$-Köhler theory, aerosol size distributions and chemical composition measured simultaneously were used to predict $N_{\mathrm{CCN}}$. There was a good agreement between the predicted and measured $N_{\mathrm{CCN}}\left(R^{2}=0.96, N_{\text {predicted }} / N_{\text {measured }}=1.04\right)$. This study
\end{abstract}

reveals that NPF exerts large impacts on aerosol particle abundance and size spectra; thus, it significantly promotes $N_{\mathrm{CCN}}$ and aerosol CCN activity in this urban environment. The GR of NPF is the key factor controlling the newly formed particles to become CCN at all SS levels, whereas the FR is an effective factor only under high SS (e.g., 1.0\%) conditions.

\section{Introduction}

Atmospheric aerosols exert great impacts on global climate by affecting earth's radiation balance through directly scattering and absorbing solar and terrestrial lights, and indirectly modifying clouds by acting as cloud condensation nuclei (CCN) (Charlson et al., 1992; Lohmann et al., 2005). The indirect effect of primary and secondary aerosols brings up the largest uncertainty to predictions of aerosol radiative forcing and global climate change (IPCC, 2013). So far, many studies of field observation and modeling have found that new particle formation (NPF) significantly impacts aerosols and CCN at worldwide locations (Ghan et al., 2001; Spracklen et al., 2006, 2008; Zhang, 2010). 
Normally, NPF in the atmosphere is identified as the nucleation of gas phase precursors and subsequent condensational growth, which is a crucial secondary transformation course (Birmili et al., 2000; Kulmala et al., 2004). In fact, NPF consists of a complex set of procedures, including the formation of nanometer-size clusters from gaseous vapors, the growth of these clusters, the removal of growing clusters by coagulation with preexisting particles, and the further growth of the surviving clusters into aerosol particles, some of which are large enough to become CCN (McMurry et al., 1983, 2005; Weber et al., 1996). The NPF event can be effectively characterized by the formation rate (FR) of nucleationmode particles and the growth rate (GR) of freshly nucleated particles (Kulmala et al., 2012). On the basis of over 100 field measurements summarized by Wang et al. (2013), significant gaps still exist regarding both formation and growth rate outputs. For example, the GR varied in the range of 1$20 \mathrm{~nm} \mathrm{~h}^{-1}$ and the FR within $0.01-10 \mathrm{~cm}^{-3} \mathrm{~s}^{-1}$. Condensable gaseous precursors and their coagulation sink responsible for NPF are commonly high in megacities of developing countries (Mönkkönen et al., 2005; Wu et al., 2007). Gaseous sulfur has proved to play a vital role in the nucleation process (Petäjä et al., 2009; Kulmala et al., 2013). Atmospheric ammonia can effectively lower the surface pressure of gaseous sulfuric molecular and participates in homogeneous nucleation with gaseous sulfuric acid and water vapor (Smith et al., 2004; Sakurai et al., 2005; Gaydos et al., 2005). In addition, there are other species responsible for NPF such as amines (Yu et al., 2012; Benson et al., 2011), low-volatility organic vapors (Metzger et al., 2010; Paasonen et al., 2010; Riipinen et al., 2011; Ehn et al., 2014) and iodine compounds (O’Dowd et al., 2002; Vuollekoski et al., 2009).

The newly formed particles from atmospheric nucleation are often able to grow into $\mathrm{CCN}$ size and further influence cloud properties or even global climate (Kerminen et al., 2005; Laaksonen et al., 2005; Wiedensohler et al., 2009). Kerminen et al. (2012) present a synthesis of our current (end of 2012) knowledge on CCN production associated with atmospheric nucleation, and conclude that $\mathrm{CCN}$ production associated with atmospheric nucleation is both a frequent and widespread phenomenon in numerous types of continental boundary layers, and probably also for a large fraction of the free troposphere. The latest model results show that the NPF events contribute much more to the global aerosol number burden than primary emissions (Merikanto et al., 2009; Yu et al., 2008). Under numerous atmospheric conditions aerosol has a positive feedback to $\mathrm{CCN}$ number concentration $\left(N_{\mathrm{CCN}}\right)$ (Ramanathan et al., 2001; Laaksonen et al., 2005), and $N_{\mathrm{CCN}}$ usually exhibits a significant increase after NPF (O'Dowd et al., 2001; Lihavainen et al., 2003; Kuwata et al., 2008; Yue et al., 2011). Due to various chemical species involved in NPF, the extent of NPF effects on CCN varied temporarily and spatially (Spracklen et al., 2008; Pierce and Adams, 2009). The long-term NPF observations were mainly conducted in Europe and North
America, whereas little has been done in developing countries (Wang et al., 2013). To date, only a few studies have focused on NPF and its interaction with CCN in China. Yue et al. (2011) reported that the GR of sulfur-poor NPF was on average about $80 \%$ larger than that of sulfur-rich NPF, and that the NPF events increased CCN by 0.4-6 times in Beijing, where various source apportionments of $\mathrm{PM}_{2.5}$ were reported by Zhang et al. (2013). Wiedensohler et al. (2009) found that the $\mathrm{CCN}$ size distribution is dominated by the growing nucleation mode in Beijing, which accounted for up to $80 \%$ of the total CCN number concentration, in contrast to the usually found phenomenon of the dominance by the accumulation mode.

In the present study, we analyze a comprehensive data set of 1 month of simultaneous measurements of aerosol size spectra, $N_{\mathrm{CCN}}$, black carbon (BC), water-soluble ions and gaseous pollutants to understand the NPF events and their impacts on $N_{\mathrm{CCN}}$ and aerosol CCN activity in an urban environment of Shanghai, one of the largest cities in China. A closure study between predicted and measured $\mathrm{CCN}$ is also conducted to investigate the influence of aerosol chemical composition on its growth to $\mathrm{CCN}$. An effective $\mathrm{CCN}$ prediction model is further developed based on model-measurement comparison results.

\section{Experimental}

\subsection{Observational site}

All instruments were mounted on the roof of one building approximately $20 \mathrm{~m}$ above the ground in the campus of Fudan University $\left(31^{\circ} 18^{\prime} \mathrm{N}, 121^{\circ} 29^{\prime} \mathrm{E}\right)$ located in Shanghai. The observational site is mainly surrounded by urban residential areas, where no large local emission was detected during this study. The East China Sea is approximately $40 \mathrm{~km}$ east of the site. Except for CCN, other measurements were conducted synchronously, including aerosol number size distribution (condensation nuclei $(\mathrm{CN})$ of $10-800 \mathrm{~nm}$ ), major inorganic water-soluble ions in aerosol particles, gaseous pollutants and meteorological factors. Local time (LT) used in this study is $8 \mathrm{~h}$ ahead of UTC (universal time coordinated).

\subsection{Measurement and instrumentation}

A CCN counter (CCN-100, DMT, USA) with continuous flow and a single column (Roberts and Nenes, 2006; Lance et al., 2006) was employed to monitor CCN concentrations at supersaturated conditions (SS in the range of 0.07-2\%). Before the campaign, the instrument was calibrated for SS using standard $\left(\mathrm{NH}_{4}\right)_{2} \mathrm{SO}_{4}$ particles. To maintain stable SS, according to the instrument operation manual, regular calibrations were also performed for temperature gradient, input and shear airflows and pressure (Leng et al., 2013). In addition, periodic zero checks were done to ensure counting accuracy for the optical particle counter (OPC) installed inside 
the $\mathrm{CCN}$ counter. The ambient aerosol was firstly dried by a dryer (active carbon) to lower relative humidity (RH) below $30 \%$, and subsequently introduced into the $\mathrm{CCN}$ counter (Leng et al., 2013).

Aerosol particle size distributions in the size range of 10$800 \mathrm{~nm}$ were measured using a high-resolution scanning mobility particle sizer (SMPS, TSI 3080, USA). Before and after the field campaign, the instrument was calibrated to maintain accurate particle sizing. The SMPS data are recorded by AIM (Aerosol Instrument Management) software from TSI. The SMPS 3936 (TSI) is employed to track the size distribution change, in which the CPC 3736 (TSI) is used to count the number of particles of each size. The neutralizer 3077a (TSI) is used in the system to provide the known charge on the particles going into the SMPS. The size of the employed impactor is $0.071 \mathrm{~cm}$. Both a multiple charge and the diffusion correction are applied. The inlet information has been reported in our previous papers (Wang et al., 2009; Huang et al., 2013).

$\mathrm{BC}$ was measured by an online monitored aethalometer (AE-31, Magee Scientific Co., Berkeley, California, USA) at a 5 min time resolution and a $5 \mathrm{~L} \mathrm{~min}^{-1}$ airflow rate. According to the strong ability of BC light absorption at near infrared wavelengths (Hansen et al., 1984; Weingartner et al., 2003), BC mass is determined using the light attenuation at $880 \mathrm{~nm}$ and the appropriate specific attenuation cross section proportional to BC (Petzold et al., 1997). The attenuation can be calculated based on the intensity difference of reference and sensing beams between light on and off (Dumka et al., 2010). In order to screen the impacts of other absorptive material, the data contaminated by mineral and dust aerosols were excluded from BC measurements. Details for instrument operation and calibration can be found in Cheng et al. (2010)

A monitor of aerosols and gases (MARGA, ADI 2080, the Netherlands) was employed to measure the mass concentrations of major inorganic water-soluble ions $\left(\mathrm{Na}^{+}, \mathrm{K}^{+}, \mathrm{Mg}^{+}\right.$, $\mathrm{Ca}^{+}, \mathrm{SO}_{4}^{2-}, \mathrm{Cl}^{-}, \mathrm{NO}_{3}^{-}$and $\mathrm{NH}_{4}^{+}$) in ambient aerosol particles at a $1 \mathrm{~h}$ time resolution. The methods of sampling, operation and internal calibration of the MARGA were described in Du et al. (2011).

A continuous ambient particulate monitor (FH62C14, Thermo Scientific) was used to measure $\mathrm{PM}_{2.5}$ (particles with aerodynamic diameter smaller than $2.5 \mu \mathrm{m}$ ) concentration online. The FH62C14, continuous ambient particulate monitor, is a radiometric particulate mass monitor capable of providing real-time measurements. It incorporates timeaveraged measurements of an integral beta attenuation sensor and advanced firmware to optimize the continuous mass measurement. The FH62C14 equips a dynamic heating system (DHS) to maintain the relative humidity $(\mathrm{RH})$ of the air passing through the filter tape of the radiometric stage well below the point at which the collected particles accrete and retain liquid water. The DHS system minimizes the internal temperature rise ensuring negligible loss of semivolatiles

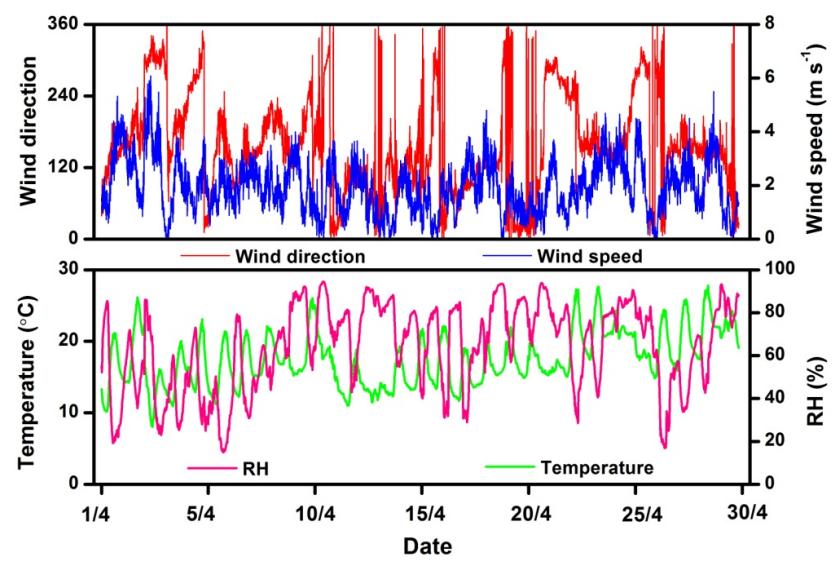

Figure 1. Series of $10 \mathrm{~min}$ mean meteorological parameters over the entire campaign.

from the collected sample when the ambient $\mathrm{RH}$ is below the threshold to which the heater is controlling. As the ambient RH increases above the threshold, the applied heating is optimized to maintain the RH threshold above the beta attenuation filter tape. Necessary sensor calibrations are regularly performed for temperature, relative humidity, barometric pressure and volumetric flow to maintain valid measurements.

Moreover, an automatic weather station client (HydroMet $^{\mathrm{TM}}$, Vaisala) and a visibility monitor (Belford, M6000) were employed to collect the data of meteorological variables and atmospheric visibility.

\section{Results and discussion}

\subsection{Overview of the entire period}

The ground-based measurements contained $N_{\mathrm{CCN}}$ at $\mathrm{SS}$ of $0.2-1.0 \%$, aerosol size spectra, atmospheric visibility, $\mathrm{PM}_{2.5}, \mathrm{BC}$, aerosol inorganic water-soluble ions and $\mathrm{SO}_{2}$ and were conducted during the period of 1-30 April 2012. Figure 1 describes the general meteorological conditions (e.g., wind speed, wind direction, RH and temperature) for the entire period. Wind frequently changed direction and was mostly weaker than $6 \mathrm{~m} \mathrm{~s}^{-1}$. There was no significant precipitation in this month and RH seldom exceeded $90 \%$. Temperature generally varied between 10 and $25^{\circ} \mathrm{C}$.

Figure 2 shows the temporal variations of 5 min mean $\mathrm{SO}_{2}$, $\mathrm{PM}_{2.5}$ concentration and atmospheric visibility for the entire period. In general, $\mathrm{PM}_{2.5}$ and visibility were negatively correlated and averaged $70 \pm 60 \mu \mathrm{g} \mathrm{m}^{-3}$ and $24.3 \pm 23.7 \mathrm{~km}$, respectively. The maximum and average of $\mathrm{PM}_{2.5}$ in the current study are of smaller magnitude than those measured in a previous study in 2006, in this urban environment, which showed a range of $17.8-217.9 \mu \mathrm{g} \mathrm{m}^{-3}$ and an average of $94.6 \mu \mathrm{g} \mathrm{m}^{-3}$ (Wang et al., 2006). $\mathrm{PM}_{2.5}$ frequently 


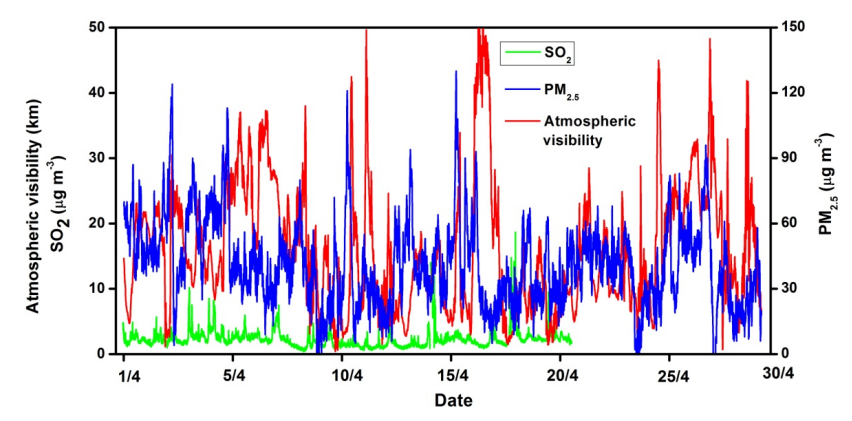

Figure 2. Series of 5 min mean $\mathrm{SO}_{2}$ and $\mathrm{PM}_{2.5}$ concentrations and atmospheric visibility over the entire campaign.

experienced a clear interday oscillating with a similar intraday cycle. $\mathrm{PM}_{2.5}$ can reflect the variations of ambient particulate pollutant loadings in the boundary atmosphere layer, and can be viewed as an additional proxy of preexisting particle amounts for identifying NPF. In a broad view, atmospheric visibility frequently decreased to less than $10 \mathrm{~km}$, revealing the occurrence of heavy pollution episodes (e.g., haze). In fact, the haze or hazy days accounted for $50 \%$ of the study period, during which atmospheric visibility was on average $5.65 \mathrm{~km}$, while it was $24.3 \mathrm{~km}$ on average for the rest of the days.

\subsubsection{New particle formation events}

It has been widely accepted that the key criterion for discerning an NPF event is to identify an acute burst of nucleationmode particles, known as newly formed particles up to a detectable size of $3 \mathrm{~nm}$ exceeding the background level, lasting for several hours, and with subsequent growth in mean particle size (Birmili and Wiedensohler, 2000; Kulmala et al., 2004, 2012; Vakkari et al., 2011). The supplementary criteria are also needed for identifying NPF: low preexisting particle loading, an apparent "banana" shaped particle number concentration as a function of time and size, and favorable weather conditions essential for excluding preexisting particle disturbance particularly in an urban environment (Shi et al., 2001; Heintzenberg et al., 2007; Olofson et al., 2009). In this study, although the SMPS is only capable of capturing particles no smaller than $10 \mathrm{~nm}$, the aerosol size spectrum from the SMPS measurements was available to determine NPF and to calculate the FR and GR of NPF.

In this study, the days with distinct bursts of nucleationmode (10-20 nm) particles lasting for at least $1.5 \mathrm{~h}$ from their initial outbreak to maximum in number concentration, and with apparent growth to larger sizes (e.g., 20-50 nm) for a few hours, were defined as effective NPF days. The rest of the days were defined as non-NPF days. Figure 3 shows the 1-month series of aerosol size distribution, 4 min mean total $\left(N_{\text {total }}\right)$ and nucleation-mode $\left(N_{10-20 \mathrm{~nm}}\right)$ aerosol number concentration and $1 \mathrm{~h}$ mean CCN concentration. Overall, 8 out of the 30 days were characterized as NPF days, which represented an occurrence frequency of $27 \%$ and was much higher than the $5.4 \%$ measured by Du et al. (2012) at the same site in winter. Many studies have observed greater NPF frequency during the spring in the Northern Hemisphere. For example, a seasonal NPF pattern with a spring maximum and winter minimum is typical for all Nordic stations (Dal Maso et al., 2007; Kristensson et al., 2008; Vehkamäki et al., 2004). In the North China Plain, the number of events was higher in the spring months (Wang et al., 2013). The high frequency of events during spring in urban Shanghai is probably due to the high frequency of strong wind from northern China, which helps in removing the preexisting particles in the atmosphere and further favors the occurrence of new particle formation events (Wu et al., 2008; Wang et al., 2013).

\subsubsection{Formation and growth rates, and condensation sink}

Formation and growth rates are two essential factors characterizing NPF events (Yue et al., 2011; Kulmala et al., 2012). The FR rate is theoretically defined as the mean increase rate of nucleation-mode particles in number concentration as a function of time $\left(\mathrm{d} N_{\text {nucleation }} / \mathrm{d} t\right)$ during the nucleation stage of a NPF event. In this paper, due to the losses of newly formed nucleated particles caused by coagulation, and the measurement unavailable for 3-10 nm particles, this calculation only yielded an "apparent particle formation rate" (APFR; Du et al., 2012). It should be noted that this APFR would be an underestimate in comparison with the actual formation rate. However, the GR rate refers to the mean size growing rate of nucleated particles in geometric mean diameter as a function of time during the growth stage of a NPF event, which has been described in detail elsewhere (Kulmala et al., 2001, 2004b; Dal Maso et al., 2005). The mode diameter, namely a calibrated geometric mean diameter automatically made by SMPS itself for all aerosol size bins instead of only for nucleated particles, is used to calculate particle growth rate in this study. Similarly, this calculation produces an "apparent particle growth rate" (APGR). The APGR would be an overestimate in comparison with the real growth rate due to inclusion of the GR rate caused by coagulation, which is not related to particle mass increases (Kerminen and Kulmala, 2002).

The condensation sink (CS) describes how rapidly vapor molecules can condense onto the particles and can be used to represent the preexisting particle concentrations (Kulmala et al., 2001). Its values can be directly calculated from the measured aerosol particle size distributions using Eq. (3) as follows:

$\mathrm{CS}=2 \pi D \sum \beta D_{\mathrm{p}} N$,

where $D$ is the diffusion coefficient of the condensing vapor, $\beta$ is the transitional regime correction factor and can be determined using the method from Fuchs and Sutugin (1971), $D_{\mathrm{p}}$ is the particle diameter and $N$ is the particle number 

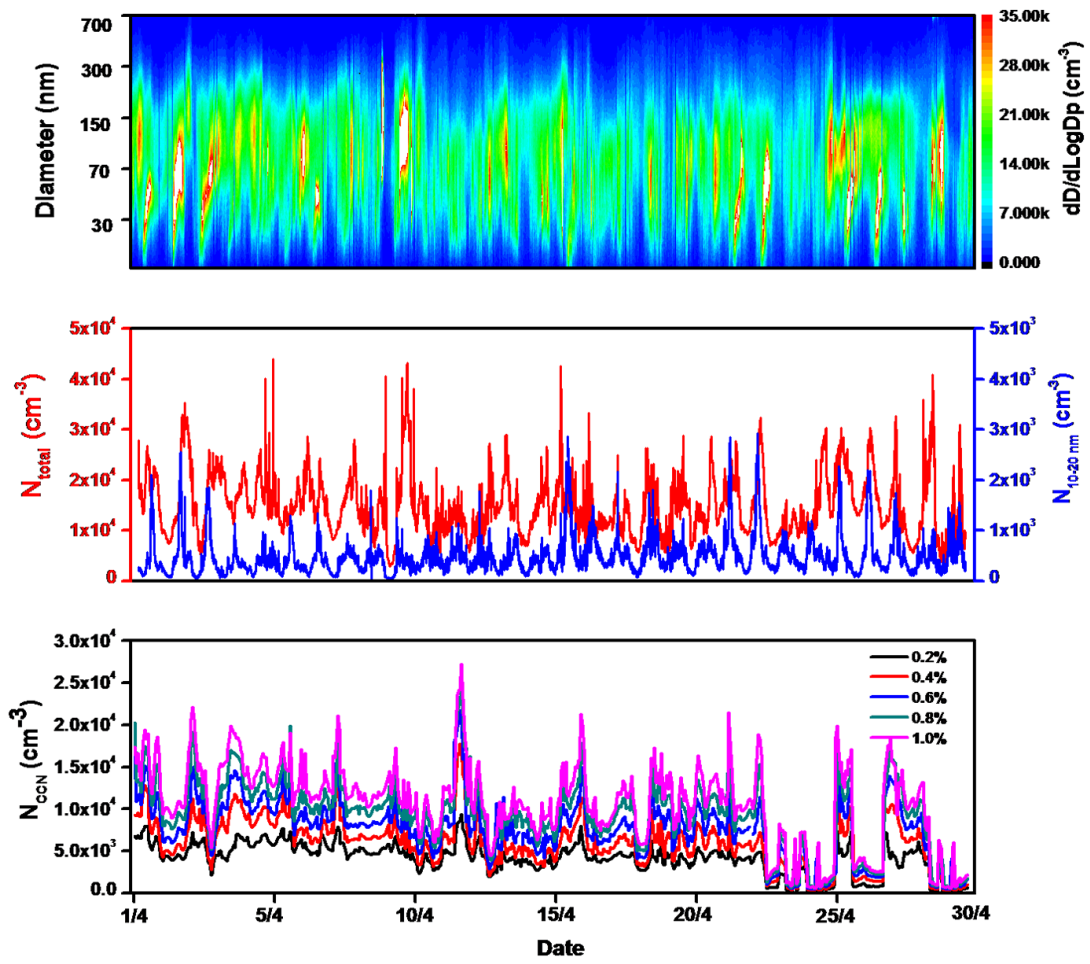

Figure 3. Series of aerosol size distribution, 4 min mean total $\left(N_{\text {total }}\right)$ and nucleation-mode aerosol number concentration $\left(N_{10-20 \mathrm{~nm}}\right)$ and $1 \mathrm{~h}$ mean $\mathrm{CCN}$ concentration over the entire campaign.

concentration of corresponding size. More explanations and the derivation process for Eq. (3) can be seen in many studies (Kulmala et al., 2001, 2005; Dal Maso et al., 2002, 2005; Gong et al., 2010; Shen et al., 2011; Gao et al., 2012; Wang et al., 2013), therefore it was only briefly summarized here. It is worth noting that this calculated CS might be underestimated compared to the real values because its derivation is based on the dry particle number size distributions, and thus incapable of representing the ambient wet condition well in this study. The uncertainty coming from the effect of ambient hygroscopic growth of aerosols on the CS ranges from 5 to $50 \%$ (Kulmala et al., 2001).

The mean formation and growth rates of NPF events were $0.40 \mathrm{~cm}^{-3} \mathrm{~s}^{-1}$ and $4.91 \mathrm{~nm} \mathrm{~h}^{-1}$, respectively, during the whole campaign. The formation and growth rates showed a strong location dependence, for example, higher formation and growth rates have been observed in New Delhi $\left(3.3-13.9 \mathrm{~cm}^{-3} \mathrm{~s}^{-1}, 11.6-18.1 \mathrm{~nm} \mathrm{~h}^{-1}\right)$ and Atlanta (20$\left.70 \mathrm{~cm}^{-3} \mathrm{~s}^{-1}\right)$, while comparable values were measured in Beijing $\left(6 \mathrm{~cm}^{-3} \mathrm{~s}^{-1}, 4 \mathrm{~nm} \mathrm{~h}^{-1}\right)$ for sulfur-rich aerosol types and $\left(2 \mathrm{~cm}^{-3} \mathrm{~s}^{-1}, 6 \mathrm{~nm} \mathrm{~h}^{-1}\right)$ for sulfur-poor aerosol types and in Shanghai $\left(3.3-5.5 \mathrm{~nm} \mathrm{~h}^{-1}\right.$ ) (Kulmala et al., 2004; Mönkkönen et al., 2005; Yue et al., 2011; Du et al., 2012). The mean CS values were $0.021 \mathrm{~s}^{-1}$ on the NPF event days and $0.040 \mathrm{~s}^{-1}$ on the non-event days, lower than those measured in Beijing $\left(0.027 \pm 0.021\right.$ and $\left.0.047 \pm 0.024 \mathrm{~s}^{-1}\right)$ and New Delhi $\left(0.050-0.070 \mathrm{~s}^{-1}\right)$, and higher than those ob- served in Shangdianzi (SDZ, a regional station located in the North China Plain, about $120 \mathrm{~km}$ northeast of Beijing, $0.020 \pm 0.020$ and $\left.0.026 \pm 0.018 \mathrm{~s}^{-1}\right)$, and European urban environments including Marseille $\left(0.003-0.015 \mathrm{~s}^{-1}\right)$, Athens $\left(0.006-0.013 \mathrm{~s}^{-1}\right)$ and Helsinki $\left(0.006 \mathrm{~s}^{-1}\right)$ (Kumala et al., 2005; Hussein et al., 2008; Wang et al., 2013).

\subsubsection{NPF impacts on aerosol CCN activity}

Pierce and Adams (2007) are the first ones that present the full theoretical framework on the efficiency of CCN production resulting from nucleation. To explore the NPF potential influence on $\mathrm{CCN}$, we further examined the impacts of FR and GR rates in NPF events on $N_{\mathrm{CCN}}$ and aerosol CCN activity. Table 1 summarizes the $N_{\mathrm{CCN}}$ enhancement ratios for different FR and GR levels during the entire campaign.

It has been widely recognized that $N_{\mathrm{CCN}}$ is positively correlated to $N_{\mathrm{CN}}$ under various atmospheric conditions (Ramanathan et al., 2001; Laaksonen et al., 2005), and enhancements on $N_{\mathrm{CCN}}$ are expected after NPF events (O'Dowd et al., 2001; Kuang et al., 2009; Yue et al., 2011). Theoretically, the high FR rate produces more secondary aerosol particles (i.e., $N_{\mathrm{CN}}$ ), which may subsequently impact $N_{\mathrm{CCN}}$ if new particles grow into greater sizes (Ghan et al., 2001; Spracklen et al., 2006, 2008; Zhang, 2010). In this paper, however, $N_{\mathrm{CCN}}$ was insensitive to the FR rate of NPF at SS of $0.2-0.8 \%$, as indicated by the small differences in $N_{\mathrm{CCN}}$ 
Table 1. Comparison of CCN enhancement ratios from NPF events with different formation and growth rates.

\begin{tabular}{llllll}
\hline & $0.2 \%$ & $0.4 \%$ & $0.6 \%$ & $0.8 \%$ & $1.0 \%$ \\
\hline Enhancement ratio (FR $>0.40)$ & 1.18 & 1.84 & 1.88 & 1.84 & 1.77 \\
Enhancement ratio (FR $<0.40)$ & 1.15 & 1.89 & 1.81 & 1.77 & 1.58 \\
Enhancement ratio (GR > 4.91) & 1.25 & 1.95 & 2.03 & 1.93 & 1.72 \\
Enhancement ratio (GR < 4.91) & 1.10 & 1.79 & 1.80 & 1.74 & 1.63 \\
\hline
\end{tabular}

enhancement ratios under various FR and SS values. This finding agrees with the results of earlier studies that the nucleation of newly formed particles within the boundary layer poses a minor impact on $N_{\mathrm{CCN}}$. Carslaw et al. (2007) found that $N_{\mathrm{CCN}}$ increased only by $12-17 \%$ after a 2 orders of magnitude increase of the nucleation rate in central Europe. A similar result has been reported in Beijing (Yue et al., 2011). This can be explained in two ways. Firstly, due to the two separate and self-governed processes in particle formation and subsequent growth. A high formation rate does not necessarily correspond to a high GR rate since the newly formed particles may not grow into CCN size because of an insufficient time period. Secondly, due to the coagulation process between particles which leads to reduced $N_{\mathrm{CN}}$ and further lowers $N_{\mathrm{CCN}}$ enhancement ratios. In fact, the impact of FR in NPF on $N_{\mathrm{CCN}}$ enhancement increased with SS (Table 1). The lower critical dry diameter under higher SS for a given aerosol particle was probably the main reason. For example, according to the $\kappa$-Köhler theory (Köhler., 1936; Petters and Kreidenweis, 2007), pure $\mathrm{NaCl}$ particles can act as $\mathrm{CCN}$ only at $65 \mathrm{~nm}$ under SS $0.2 \%$, while it can be activated at $22 \mathrm{~nm}$ under SS of $1.0 \%$. Presumably, with the presence of an unrealistic high SS where all nucleation-mode particles (10$20 \mathrm{~nm}$ ) are activated, the formation rate would be one controlling factor.

Moreover, what controls whether a newly formed particle becomes a CCN is its survival probability and whether it has enough time to grow into thermodynamically stable size by competing with the capture and removal of preexisting particles (Kerminen et al., 2001; Pierce and Adams, 2007; Zhang et al., 2012). Toward to this end, the aerosol-GR rate of NPF responsible for this survival probability was observed to exert a valid effect on $N_{\mathrm{CCN}}$ enhancement ratios. As was found in this study, the $N_{\mathrm{CCN}}$ enhancement ratios at a larger GR rate were higher than those at a lower GR rate by a factor of 1.06-1.13, depending on SS.

Overall, the $N_{\mathrm{CCN}}$ enhancement ratios due to NPF varied as a function of FR and GR rates and SS. In the real atmosphere, SS varies from exceeding $1.0 \%$ in clean-air stratus clouds to slightly less than $0.1 \%$ in polluted conditions (Hudson and Noble, 2014). The FR may logically play a vital role in CCN production in the clean-air stratus clouds, while exerting a minor impact in polluted conditions. GR is invariably the most important factor in controlling the extent of newly formed particles in becoming CCN during NPF.

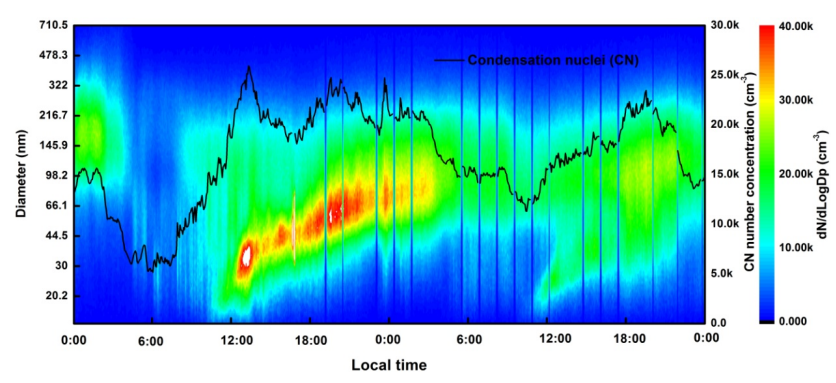

Figure 4. Temporal evolution of 4 min mean aerosol size spectra, showing new particle formation and subsequent growth on 3 and 4 April 2012.

\subsection{Characteristics of a typical NPF}

\subsubsection{Increased concentrations of nanoparticles}

The NPF event spanning the period from 10:00 LT on 3 April to 04:00 LT on 4 April is analyzed in detail to shed some light on the relationship between NPF and CCN. This NPF event was identified to consist of a nucleation stage (10:0013:00 LT) and a growth stage (13:00-04:00 LT) (Fig. 4).

Before 10:00 LT on 3 April, $\mathrm{PM}_{2.5}$ was below $20 \mu \mathrm{g} \mathrm{m}^{-3}$ due to the relatively strong wind speed (e.g., $6 \mathrm{~m} \mathrm{~s}^{-1}$ ) favoring pollutant dispersion. BC was less than $1 \mu \mathrm{g} \mathrm{m}^{-3}$ and atmospheric visibility exceeded $30 \mathrm{~km}$ (Figs. 5, 6). Apparently, the preexisting particles of nucleation mode (10-20 nm) were low (Fig. 7). Newly formed particles increased quickly after just $1.5 \mathrm{~h}$ from the initial outbreak to the maximum concentration of $1800 \mathrm{~cm}^{-3}$ (Fig. 7). During the same time period, $N_{\mathrm{CN}}$ increased from 15000 to $25000 \mathrm{~cm}^{-3}$. The newly formed particles grew in size in the following periods (the growth stage) due to condensation, heterogeneous reactions of chemical compounds and coagulation between particles (Wang et al., 2010). The temporal variations of median, geometric mean and mode diameters for the measured aerosol population are given in Fig. 7. In general, these three diameters were strongly correlated with each other and increased in size ever since the nucleation burst occurred. During this period, the wind speed was mostly less than $2 \mathrm{~m} \mathrm{~s}^{-1}$, implying a weak atmospheric dilution of pollutants. $\mathrm{PM}_{2.5}$ increased after 17:00 LT on 3 April, showing a significant enhancement from 38 to $86 \mu \mathrm{g} \mathrm{m}^{-3}$. In addition, BC correlated well with $\mathrm{PM}_{2.5}$, and they both reduce atmospheric visibility. 


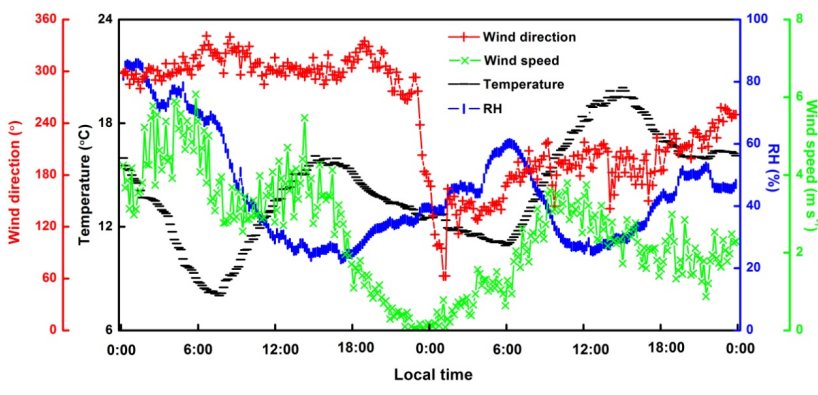

Figure 5. Temporal evolution of 10 min mean meteorological parameters during the new particle formation event on 3 and 4 April 2012.

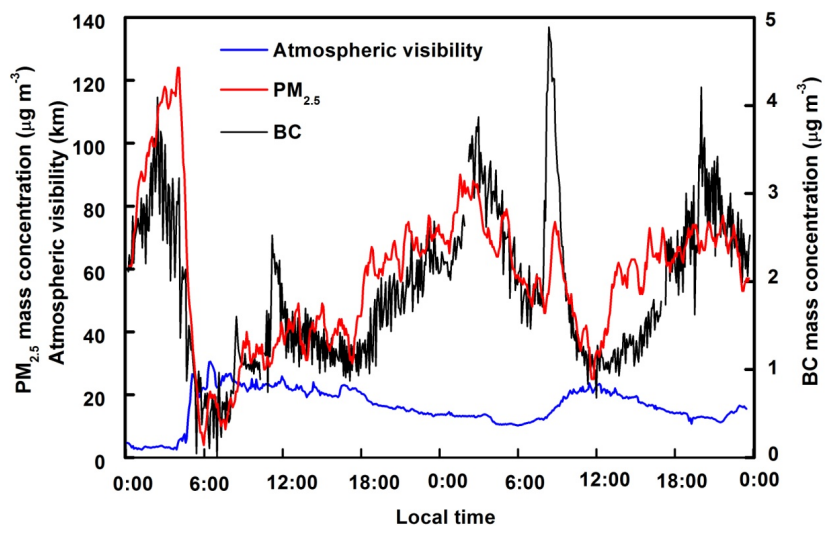

Figure 6. Temporal evolutions of 5 min mean atmospheric visibility, $\mathrm{BC}$ and $\mathrm{PM}_{2.5}$ concentrations during the new particle formation event on 3 and 4 April 2012.

\subsubsection{Insights into the chemical species involved}

Several factors likely determine if a chemical species is to act as nucleation precursor, including its abundance, reactivity and volatility (Zhang et al., 2012). Gaseous $\mathrm{H}_{2} \mathrm{SO}_{4}$ has been proved to be a key precursor participating in the nucleation process due to its low volatility (Petäjä et al., 2009; Kulmala et al., 2013), and a necessary condition for new particle formation is for its molecular concentration to exceed $10^{5} \mathrm{~cm}^{-3}$ in atmosphere (Weber et al., 1999; Nieminen et al., 2009). The condensation of gaseous $\mathrm{H}_{2} \mathrm{SO}_{4}$ together with subsequent neutralization with ammonia plays a dominant role in the growth of Aitken-mode particles, whereas it exerts little contribution to the growth of particles in accumulation mode (Zheng et al., 2011).

However, the direct measurement of sulfuric acid in ambient air is still challenging, appropriate proxies are needed. Petäjä et al. (2009) measured the sulfuric acid and OH concentration in a boreal forest site in Finland and successfully developed three reasonable proxies for sulfuric acid concentration by using the measured time series as a foundation. Their proxies refer to source (i.e., gaseous $\mathrm{SO}_{2}$, hydroxyl radical, solar radiation in the $280-320 \mathrm{~nm}$ range, and global

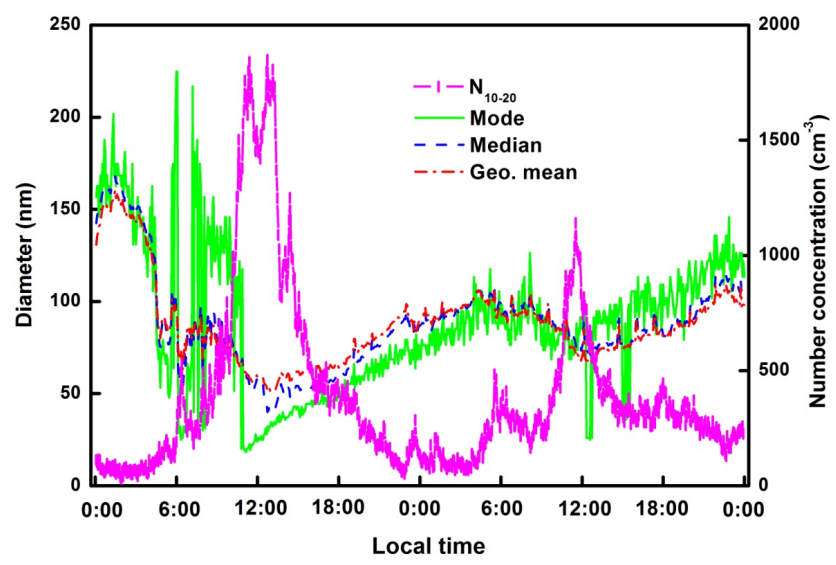

Figure 7. Temporal evolutions of 4 min mean mode, median and diameters and 10-20 nm particle concentration, showing the growth rate and formation of new particles on 3 and 4 April 2012.

radiation) and sink (i.e., condensation sink) terms, and the simplest one is the radiation multiplied by the $\mathrm{SO}_{2}$ and divided by the condensation sink. In this paper, the source and radiation terms are unavailable; one may plausibly conjecture a similar formation of $\mathrm{H}_{2} \mathrm{SO}_{4}$ on the basis of its gaseous precursor (e.g., $\mathrm{SO}_{2}$ ) evolution (Zhang et al., 2012).

$\mathrm{SO}_{2}+\mathrm{OH} \stackrel{\mathrm{O}_{2} \mathrm{H}_{2} \mathrm{O}}{\longrightarrow} \mathrm{H}_{2} \mathrm{SO}_{4}$

The particle nucleation event showed a burst of 10-20 nm particles when $\mathrm{SO}_{2}$ peaked at 10:00 LT on 3 April, with its mass and molar concentrations exceeding $4.1 \mu \mathrm{g} \mathrm{m}^{-3}$ and $3.8 \times 10^{10} \mathrm{~cm}^{-3}$, respectively (Fig. 8). Afterwards, $\mathrm{SO}_{2}$ underwent a gradual decrease down to $1.5 \mu \mathrm{g} \mathrm{m}^{-3}$, and $\mathrm{SO}_{4}^{2-}$ correspondingly increased from 8 to $10 \mu \mathrm{g} \mathrm{m}^{-3}$. The good agreement between $\mathrm{SO}_{2}$ and nucleation-mode particles denotes the key role of gaseous sulfur in controlling particle nucleation (Zhang et al., 2012; Kulmala et al., 2013).

Besides gaseous sulfur, other nucleation precursors have been proposed to be involved in the critical nucleus formation in numerous environment conditions (Riipinen et al., 2011; Zhang et al., 2012). For example, atmospheric ammonia can significantly lower the surface vapor pressure of gaseous sulfuric acid molecules and participate in homogeneous nucleation with gaseous sulfuric acid and water vapor. According to the classical ternary homogeneous theory developed recently, the presence of ammonia in partsper-trillion levels significantly enhances nucleation rates ( $\mathrm{Yu}$ et al., 2006). Many field measurements and laboratory simulations have corroborated the crucial role of ammonia in the growth of newly formed particles (Smith et al., 2004; Sakurai et al., 2005; Gaydos et al., 2005). Though experimental evidence seems very limited, nitrate has been reported as a crucial contributor to nanoparticle growth, especially for $10-30 \mathrm{~nm}$ particles where nitrate is dominant (Hildebrandt et al., 2012). Riipinen et al. (2011) combined 


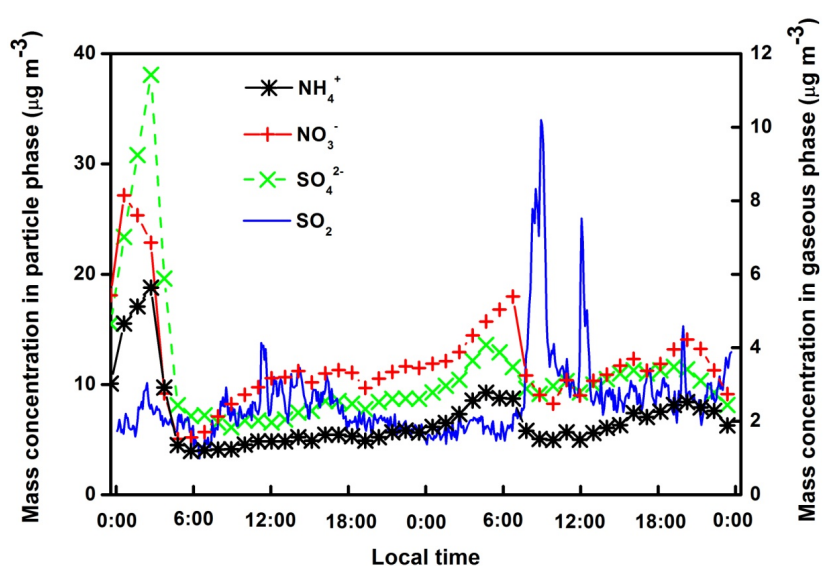

Figure 8. Series of $1 \mathrm{~h}$ mean $\mathrm{SO}_{2}, \mathrm{SO}_{4}^{2-}, \mathrm{NO}_{3}^{-}$and $\mathrm{NH}_{4}^{+}$concentrations on 3 and 4 April 2012.

observations from two continental sites to show that the condensation of organic vapors (i.e., nonvolatile and semivolatile species) is a crucial factor governing the lifetimes and climatic importance of the smallest atmospheric particles. Ehn et al. (2014) find that several biogenic VOCs (volatile organic compounds; e.g., monoterpenes) form large amounts of extremely low-volatility vapors and further demonstrate that these low-volatility vapors can enhance (or even dominate) the formation and growth of aerosol particles over forested regions. In this paper, $\mathrm{NO}_{3}^{-}$increased by a factor of 1.33 and $\mathrm{NH}_{4}^{+}$increased by a factor of 1.45 during the NPF event, indicating that the particle growth is partly driven by the condensation of atmospheric precursors (Fig. 8).

\subsubsection{Aerosol CCN activity enhancement}

Figure 9 shows the temporal evolutions of $N_{\mathrm{CCN}}$ and aerosol CCN activity at SS of $0.2-1.0 \%$ for the entire period. The enhanced $N_{\mathrm{CN}}$ and reduced aerosol CCN activity, associated with nucleation-mode-particle burst, was observed between 10:00 and 13:00 LT on 3 April. In contrast to $N_{\mathrm{CN}}$ which increased immediately after the burst of nucleationmode particles, there was a $4 \mathrm{~h}$ delay in the increase of $N_{\mathrm{CCN}}$. As the newly formed particles grew into larger sizes, both $N_{\mathrm{CCN}}$ and aerosol CCN activity increased at various stages under different SS. At a SS higher than $0.4 \%, N_{\mathrm{CCN}}$ peaked at 20:00 LT on 3 April. $N_{\mathrm{CCN}}$ greatly increased from 8000 $12000 \mathrm{~cm}^{-3}$ to $10000-20000 \mathrm{~cm}^{-3}$ under higher SS, however, only slightly from 6000 to $7000 \mathrm{~cm}^{-3}$ under lower SS (e.g., $0.2 \%$ ). A larger critical dry diameter corresponding to lower SS should be the main reason. For example, the critical dry diameter for pure $\left(\mathrm{NH}_{4}\right)_{2} \mathrm{SO}_{4}$ particles was $83 \mathrm{~nm}$ at SS of $0.2 \%$ and was only $29 \mathrm{~nm}$ at SS of $1.0 \%$. The newly formed particles rarely grew larger than $83 \mathrm{~nm}$ in size in this NPF event, hence less $N_{\mathrm{CCN}}$ enhancement was expected at SS of $0.2 \%$. In summary, the $N_{\mathrm{CCN}}$ enhancement ratios were 1.17-1.88 depending on SS value. In Beijing, a larger

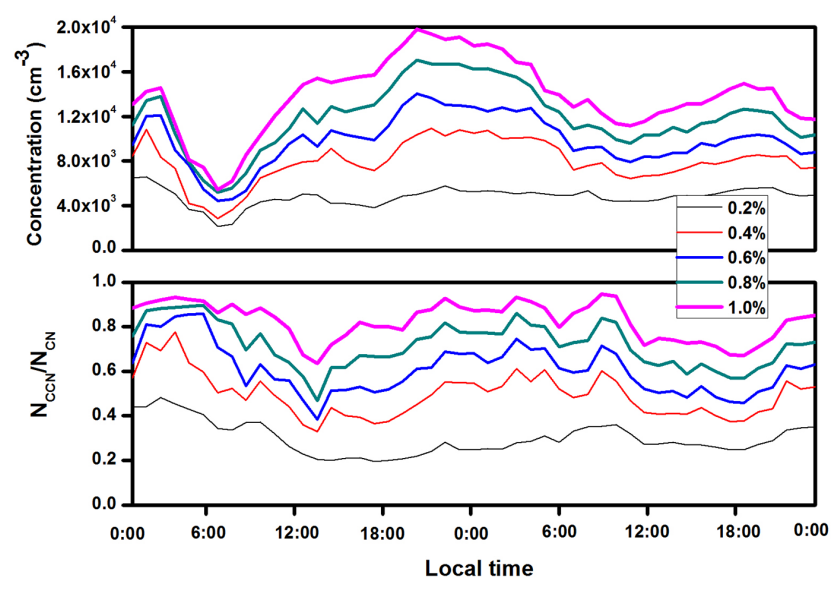

Figure 9. Series of $1 \mathrm{~h}$ mean $\mathrm{CCN}$ concentration and $\mathrm{CCN} / \mathrm{CN}$ on 3 and 4 April 2012.

Table 2. Effective hygroscopicity parameters $(\kappa)$ and densities of the four category compositions.

\begin{tabular}{llrc}
\hline Species & Data source & $\kappa$ & $\begin{array}{c}\text { Density } \\
\left(\mathrm{g} \mathrm{cm}^{-3}\right)\end{array}$ \\
\hline Sulfate and nitrate & $\mathrm{SO}_{4}^{2-}+\mathrm{NO}_{3}^{-}+\mathrm{NH}_{4}^{+}$ & 0.6 & 1.7 \\
Sodium chloride & $\mathrm{Cl}^{-}+\mathrm{Na}^{+}$ & 1 & 2.2 \\
Insoluble compounds & Others & 0 & 2.0 \\
\hline
\end{tabular}

$N_{\mathrm{CCN}}$ enhancement ratio of 1.4-7 was observed under SS of $0.07-0.86 \%$ caused by NPF (Yue et al., 2011). In comparison with $N_{\mathrm{CCN}}$, aerosol CCN activity was more sensitive to aerosol size spectra and meteorology factors, which exerts a big complexity into the temporal variation of aerosol activation. Aerosol activities were effectively reduced by abundant ultrafine aerosol particles (CCN-inert) produced during the nucleation period. The minimum (0.2-0.6) of aerosol activities was found at 13:00 LT in April when the particle growth started. Owing to the high survival probability of particles growing from nucleation mode to accumulation mode (CCN size), aerosol activities began to increase at different steps for varying SS and reached their maximums of $0.3-0.9(0.2-$ $1.0 \% \mathrm{SS}$ ) at 04:00 LT on 4 April, $8 \mathrm{~h}$ after $N_{\mathrm{CCN}}$ peaked.

\subsubsection{Towards CCN closure for NPF}

A kappa value, $\kappa$, describing particle hygroscopicity, firstly introduced by Petters and Kreidenweis (2007), was employed here for a CCN closure study during NPF. Assuming aerosol particle population is totally internally mixed, the effective integrated $\kappa$ can be obtained through weighting their chemical compound volume factions,

$\kappa=\sum_{i} \varepsilon_{i} \kappa_{i}$, 
where $\varepsilon_{i}$ is the volume fraction of chemical compounds in particles, and $\kappa_{i}$ is the effective $\kappa$ of individual chemical composition. This equation has been widely used and described in detail elsewhere (Petters and and Kreidenweis., 2008; Yue et al., 2011). Aerosol particle compositions were classified into three categories, and $\kappa_{i}$ and $\varepsilon_{i}$ for individual composition are listed in Table 2, of which "others" refers to $\mathrm{PM}_{2.5}-\left(\mathrm{SO}_{4}^{2-}+\mathrm{NO}_{3}^{-}+\mathrm{NH}_{4}^{+}+\mathrm{Cl}^{-}+\mathrm{Na}^{+}\right)$, and is viewed as a chemical compound with $\kappa_{i}=0$ (Yue et al., 2011). Due to MARGA data limitations, we only attempted to get CCN closure for the NPF event in this study. The hourly mean $\kappa$ values varied from 0.19 to 0.42 , and had an average of 0.28 during the NPF event. In total, $83.2 \%$ of the effective $\kappa$ was explained by $\mathrm{SO}_{4}^{2-}+\mathrm{NO}_{3}^{-}+\mathrm{NH}_{4}^{+}$, with their individual contributions of 37.4, 27.5 and $18.3 \%$, respectively. By using the calculated $\kappa$, the critical dry diameter for a particle to act as $\mathrm{CCN}$ at a given SS can be determined from an extended $\kappa$-Köhler theory:

$S(D)=\frac{D^{3}-D_{\mathrm{d}}^{3}}{D^{3}-D_{\mathrm{d}}^{3}(1-\kappa)} \exp \left(\frac{4 \sigma_{\mathrm{s} / \mathrm{a}} M_{\omega}}{\mathrm{RT} \rho_{\omega} D}\right)$,

where $\rho_{\omega}$ is the density of water, $M_{\omega}$ is the molecular weight of water, $\sigma_{s / a}$ is the surface tension of the solution-air interface, $R$ is the universal gas constant, $\kappa$ is the hygroscopicity parameter, $T$ is temperature, $D$ is the diameter of the droplet and $S(D)$ is the critical dry size under a given SS. A moredetailed explanation and the derivation process of Eq. (3) are given by Petters and Kreidenweis (2007), this is only a brief summary. The $\mathrm{CCN}$ population can be effectively viewed as a subset of measured aerosol size distributions since the operating range includes the majority of atmospheric particles $(10-800 \mathrm{~nm})$. Computed for $\sigma_{\mathrm{s} / \mathrm{a}}=0.072 \mathrm{~J} \mathrm{~m}^{-2}$ and $T=298.15 \mathrm{~K}$, the predicted CCN number concentration can be calculated through integration between the bottom and top critical dry diameters (i.e., $S(D)$ ).

Figure 10 provides a correlation analysis for the hourly averaged $(N=90)$, predicted and measured $N_{\mathrm{CCN}}$ at SS of $0.2-$ $1.0 \%$. The agreement was excellent between the predicted and measured $N_{\mathrm{CCN}}$, and a linear regression produced a slope of 0.98 and an intercept of $-150 \mathrm{~cm}^{-3}$, with a correlation coefficient $\left(R^{2}\right)$ of 0.96 . The ratio of $N_{\text {predicted }} / N_{\text {measured }}$ varied between 0.83 and 1.28 with an average of 1.04 .

\section{Conclusions}

The new particle formation (NPF) events and their impacts on the abundance and properties of cloud condensation nuclei $(\mathrm{CCN})$ were investigated using 1 month of continuous measurements collected in downtown Shanghai from 1 to 30 April 2012. The NPF events were observed in 8 out of the 30 days, and their formation and growth rates were $0.40 \mathrm{~cm}^{-3} \mathrm{~s}^{-1}$ and $4.91 \mathrm{~nm} \mathrm{~h}^{-1}$, on average, respectively. The growth rate is important in controlling the conversion of newly formed particles in NPF to possible CCN,

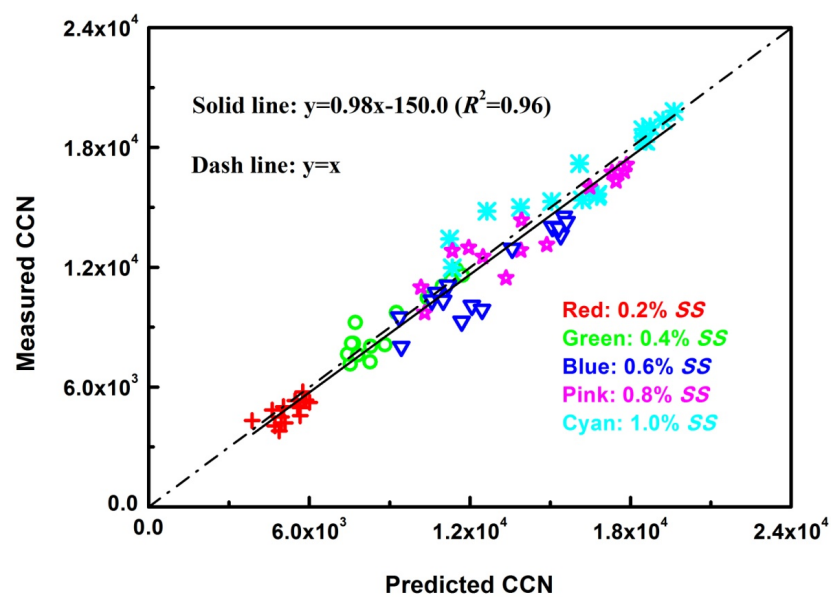

Figure 10. Scatterplots of predicted and measured CCN concentrations $\left(\mathrm{cm}^{-3}\right)$ at different SS conditions, the red dash line represents $y=x$.

whereas the formation rate is viewed as an effective factor only at higher SS (e.g., 1.0\%). This is due to the small critical dry diameters for particles, necessary in order to act as CCN under high SS conditions.

The NPF event on 3 April 2012 showed that aerosol particle enhancement in number concentration significantly relates to the length of nucleation period of NPF, and that aerosol particle enhancement in mass concentration depends on the growth period. The nucleation period leads to increased $N_{\mathrm{CN}}$ and reduced aerosol activity, while the increases in $N_{\mathrm{CCN}}$ and aerosol activity occurred during the growth period. The newly formed particles needed enough time to grow into CCN size and thus $N_{\mathrm{CCN}}$ had a delayed peak compared to $N_{\mathrm{CN}}$.

Closure between the measured and predicted $N_{\mathrm{CCN}}$ was successful during the NPF event $\left(R^{2}=0.96\right)$. $\mathrm{SO}_{4}^{2-}+\mathrm{NO}_{3}^{-}+\mathrm{NH}_{4}^{+}$explained the majority of the effective $\kappa$, and minimized the impact of lacking organic matter. An overestimation of $4 \%$ for $N_{\mathrm{CCN}}$ is probably introduced by the following uncertainties: (1) aerosol assumed to be completely internally mixed, which is an unrealistic condition and hardly realized in the real atmosphere; (2) errors introduced by $\kappa_{i}$ for individual chemical composition; and (3) the category "others" typically includes organic carbon (OC), elemental carbon (EC), hydrophobic inorganic and other species. Among these other species there are water soluble species contributing to $\mathrm{CCN}$ formation. For example, OC has an effective $\kappa$ value of roughly 0.1 and has been reported to be an important contributor to particle condensational growth. The reasonable closure identified in this study implies that the detailed information of particle size spectra can build an effective $\mathrm{CCN}$ prediction model, and size plays a dominant role in aerosol activity during NPF. 
It should be noted that the contribution of NPF to CCN has not been fully characterized in this study. For example, the loss of nucleation-mode particles by coagulation and the impact of atmospheric dilution and boundary layer evolution on preexisting and newly formed $\mathrm{CCN}$ are unknown. To fully determine NPF contribution to $\mathrm{CCN}$, additional information on size-resolved aerosol composition, size spectra for $3 \mathrm{~nm}$ or smaller particles, atmospheric sink and physicochemical process will be needed.

Acknowledgements. This research is supported by the project China Fog-haze monitoring and its numeric forecast operational system at various scales, 2014BAC16B01, the National Natural Science Foundation of China (41475109, 41275126, 21190053, 21177025, 21177027, 21277028, 21377029), and partly by the Research and Development Special Fund for Public Welfare Industry (Meteorology) of CMA (GYHY201006047), the Shanghai Science and Technology Commission of the Shanghai Municipality (12DJ1400100, 12DZ2260200, 14XD1400600), the Jiangsu Collaborative Innovation Center for Climate Change, and Priority fields for Ph.D. Programs Foundation of the Ministry of Education of China (0110071130003), and the national nonprofit scientific research program for environmental protection (201409008).

Edited by: V.-M. Kerminen

\section{References}

Benson, D. R., Yu, J. H., Markovich, A., and Lee, S.-H.: Ternary homogeneous nucleation of $\mathrm{H}_{2} \mathrm{SO}_{4}, \mathrm{NH}_{3}$, and $\mathrm{H}_{2} \mathrm{O}$ under conditions relevant to the lower troposphere, Atmos. Chem. Phys., 11, 4755-4766, doi:10.5194/acp-11-4755-2011, 2011.

Birmili, W. and Wiedensohler, A.: New particle formation in the continental boundary layer: meteorological and gas phase parameter influence, Geophys. Res. Lett., 27, 3325-3328, doi:10.1029/1999GL011221, 2000.

Carslaw, K. S., Spracklen, D. S., Kulmala, M., Kerminen, V. M., Sihto, S. L., and Riipinen, I.: The impact of boundary layer nucleation on global CCN, Aip. Conf. Proc., 911-915, 2007.

Cheng, T. T., Han, Z. W., Zhang, R. J., Du, H. H., Jia, X., Wang, J. J., and Yao, J. Y.: Black carbon in a continental semi-arid area of Northeast China and its possible sources of fire emission, J. Geophys. Res., 115, D23204, doi:10.1029/2009JD013523, 2010.

Cheng, Y., Lee, S. C., Ho, K. F., Wang, Y. Q., Cao, J. J., Chow, J. C., and Watson, J. G.: Black carbon measurement in a coastal area of south China, J. Geophys. Res., 111, D12310, doi:10.1029/2005JD006663, 2006.

Dal Maso, M., Kulmala, M., Lehtinen, K. E. J., and Mäkelä, J. M.: Condensation and coagulation sinks and formation of nucleation mode particles in coastal and boreal forest boundary layers, J. Geophys. Res., 107, doi:10.1029/2001JD001053, 2002.

Dal Maso, M., Kulmala, M., Riipinen, I., Wagner, R., Hussein, T., Aalto, P. P., and Lehtinen, K. E. J.: Formation and growth of fresh atmospheric aerosols: eight years of aerosol size distribution data from SMEAR II, Hyytiala, Finland, Boreal Env. Res., 10, 323336, 2005.
Dal Maso, M., Sogacheva, L., Aalto, P. P., Riipinen, I., Komppula, M., Tunved, P., Korhonen, L., Suur-Uski, V., Hirsikko, A., Kurtén, T., Kerminen, V. -M., Lihavainen, H., Viisanen, Y., Hansson, H. -C., and Kulmala, M.: Aerosol size distribution measurements at four Nordic field stations: identification, analysis and trajectory analysis of new particle formation bursts, Tellus, 59B, 350-361, 2007.

Du, H. H., Kong, L. D., Cheng, T. T., Chen, J. M., Du, J. F., Li, L., Xia, X., Leng. C. P., and Huang, G. H.: Insights into summertime haze pollution events over Shanghai based on online water-soluble ionic composition of aerosols, Atmos. Environ., 45, 5131-5137, 2011.

Du, J. F., Cheng, T. T., Zhang, M., Chen, J. M., He, Q. S.,Wang, X. M., Zhang, R. J., Tao, J., Huang, G. H., Li, X., and Zha, S. P.: Aerosol size spectra and particle formation events at urban Shanghai in eastern China, Aerosol Air Qual. Res., 12, 1362-1372, 2012.

Dumka, U. C., Krishna Moorthy, K., Kumar, R., Hegde, P., Sagar, R., Pant, P., Singh, N., and Suresh Babu, S.: Characteristics of aerosol black carbon mass concentration over a high altitude location in the Central Himalayas from multi-year measurements, Atmos. Res., 96, 510-521, 2010.

Ehn, M., Thornton, J. A., Kleist, E., Sipilä, M., Juuninen, H., Pullinen, L., Springer, M., Rubach, F., Tillmann, R., Lee, B., Lopez-Hilfiker, F., Andres, S., Acir, I.-H., Rissanen, M., Jokinen, T., Schobesberger, S., Kangasluoma, J., Kontkanen, J., Nieminen, T., Kurtén, T., Nielsen, L. B., Jørgensen, S., Kjaergaard, H. G., Canagaratna, M., Maso, M. D., Berndt, T., Petäjä, T., Wahner, A., Kerminen, V.-M., Kulmala, M., Worsnop, D. R., Wildt, J., and Mentel., T. F.: A large source of low-volatility secondary organic aerosol, Nature, 506, 476-479, 2014.

Fuchs, N. A. and Sutugin, A. G.: High-dispersed aerosols in Topics in Current Aerosol Research, edited by: Hidy, G. M. and Brock, J. R., Pergamon, Oxford, 2, 1-60, 1971.

Gao, J., Chai, F. H., Wang, T., Wang, S. L., and Wang, W. X.: Particle number size distribution and new particle formation: New characteristics during the special pollution control period in Beijing, J. Environ. Sci., 24, 14-21, 2012.

Gaydos, T. M., Stanier, C. O., and Pandis, S. N.: Modeling of in situ ultrafine atmospheric particle formation in the eastern United States, J. Geophys. Res., 110, D07S12, doi:10.1029/2004JD004683, 2005.

Ghan, S. J., Easter, R. C., Chapman, E. G., Abdul-Razzak, H., Zhang, Y., Leung, L. R., Laulainen, N. S., Saylor, R. D., and Zaveri, R. A.: A physically based estimate of radiative forcing by anthropogenic sulfate aerosol, J. Geophys. Res., 106, 52795293, 2001.

Gong, Y. G., Hu, M., Cheng, Y. F., Su, H., Yue, D. L., Liu, F., Wiedensohler, A., Wang, Z. B., Kalesse, H., Liu, S., Wu, Z. J., Xiao, K. T., Mi, P. C., and Zhang, Y. H.: Competition of coagulation sink and source rate: New particle formation in the Pearl River Delta of China, Atmos. Environ., 44, 3278-3285, 2010.

Hansen, A. D. A., Rosen, H., and Novakov, T.: The aethalometer-an instrument for the real-time measurement of optical absorption by aerosol particles, Sci. Total Environ., 36, 191-196, 1984.

Heintzenberg, J., Wehner, B., and Birmili, W.: How to find bananas in the atmospheric aerosols: new approach for analyzing 
atmospheric nucleation and growth events, Tellus, 59B, 273-282, 2007.

Hildebrandt, R. L., Smith, J., Riipinen, I., Barsanti, K., Fry, J., Yli-Juuti, T., Petaja, T., Kulmala, M., and McMurry, P. H.: The role of nitrate in the formation of atmospheric nanoparticlers: insights from ambient measurements and chemical transport models, (611f) Environmental division, American Institute of Chemical Engineers Annual Meeting, Pittsburgh, PA, 1 November 2012, 2012.

Huang, Y. L., Li, L., Li, J. Y., Wang, X., Chen, H., Chen, J. M., Yang, X., Cross, D. S., Wang, H., Qiao, L. P., and Chen, H.: A case study of the highly time-resolved evolution of aerosol chemical and optical properties in urban Shanghai, China, Atmos. Chem. Phys., 13, 3931-3944, doi:10.5194/acp-13-39312013, 2013.

Hudson J. G. and Noble, S.: CCN and vertical velocity influences on droplet concentration and supersaturations in clean and polluted stratus clouds, J. Atmos. Sci., 106, 24119-24126, 2014.

Hussein, T., Martikainen, J., Junninen, H., Sogacheva, L., Wagner, R., Dal Maso, M., Riipinen, I., Aalto, P. P., and Kulmala, M.: Observation of regional new particle formation in the urban atmosphere, Tellus B, 60, 609-521, doi:10.1111/j.16000889.2008.00365.x, 2008.

IPCC: Climate Change 2013: The Physical Science Basis. Contribution of Working Group I to the Fifth Assessment Report of the Intergovernmental Panel on Climate Change, edited by: Joussaume, S., Penner, J., and Tangang, F., IPCC, Stockholm, 2013.

Kerminen, V.-M.: How significantly does coagulation scavenging limit atmospheric particle production?, J. Geophys. Res., 106, 24119-24126, 2001.

Kerminen, V.-M., Lihabainen, H., Lomppula, M., Viisanen, Y., and Kulmala, M.: Direct observational evidence linking atmospheric aerosol formation and cloud droplet activation, Geophys. Res. Lett., 32, L14803, doi:10.1029/2005GL023130, 2005.

Kerminen, V.-M., Paramonov, M., Anttila, T., Riipinen, I., Fountoukis, C., Korhonen, H., Asmi, E., Laakso, L., Lihavainen, H., Swietlicki, E., Svenningsson, B., Asmi, A., Pandis, S. N., Kulmala, M., and Petäjä, T.: Cloud condensation nuclei production associated with atmospheric nucleation: a synthesis based on existing literature and new results, Atmos. Chem. Phys., 12, $12037-$ 12059, doi:10.5194/acp-12-12037-2012, 2012.

Köhler, H.: The nucleus in and the the growth of hygroscopic droplets, T. Faraday Soc., 32, 1152-1161, 1936.

Kristensson, A., Dal Maso, M., Swietlicki, E., Hussein, T., Zhou, J., Kerminen, V.-M., and Kulmala, M.: Characterization of new particle formation events at a background site in Southern Sweden: relation to air mass history, Tellus 60B, 330-344, doi:10.1111/j.1600-0889.2008.00345.x, 2008.

Kulmala, M., Dal Maso, M., Mäkelä, J. M., Pirjola, L., Väkevä, M., Aalto, P., Miikkulainen, P., Hämeri, K., and O'Dowd, C. D.: On the formation, growth and composition of nucleation mode particles, Tellus B, 53, 479-490, 2001.

Kulmala, M., Laakso, L., Lehtinen, K. E. J., Riipinen, I., Dal Maso, M., Anttila, T., Kerminen, V.-M., Hörrak, U., Vana, M., and Tammet, H.: Initial steps of aerosol growth, Atmos. Chem. Phys., 4, 2553-2560, doi:10.5194/acp-4-2553-2004, 2004.

Kulmala, M., Petäjä, T., Mönkkönen, P., Koponen, I. K., Dal Maso, M., Aalto, P. P., Lehtinen, K. E. J., and Kerminen, V. -M.: On the growth of nucleation mode particles: source rates of condensable vapor in polluted and clean environments, Atmos. Chem. Phys. 5, 409-416, doi:10.5194/acp-5-409-2005, 2005.

Kulmala, M., Petäjä, T., Nieminen, T., Sipilä, M., Manninen, H. E., Lehtipato, K., Dal Maso, M., Aalto, P. P., Junninen, H., Paasonen, P., Riipinen, I., Lehtinen, K. E., Laaksonen, A., and Kerminen, V. M.: Measurement of the nucleation of atmospheric aerosol particles, Nat. Prodoc., 7, 1651-1667, 2012.

Kulmala, M., Kontkanen, J., Junninen, H., Lehtipalo, K., Manninen, H. E., Nieminen, T., Petäjä, T., Sipilä, M., Schobesberger, S., Rantala, P., Franchin, A., Jokinen, T., Järvinen, E., Äijälä, M., Kangasluoma, J., Hakala, J., Aalto, P. P., Paasonen, P., Mikkilä, J., Vanhanen, J., Aalto, J., Hakola, H., Aakkonen, U., Ruuskanen, T., Mauldin III, R. L., Duplissy, J., Vehkamäki, H., Bäck, J., Kortelainen, A., Riipinen, L., Kurtén, T., Johnston, M. V., Smith, J. N., Ehn, M., Mentel, T. F., Lehtinen, K. E. J., Laaksonen, A., Kerminen, V.M., and Worsnop, D. R.: Direct observations of atmospheric aerosol nucleation, Science, 339, 943-946, 2013.

Kuwata, M. and Kondo, Y.: Dependence of size-resolved CCN spectra on the mixing state of nonvolatile cores observed in Tokyo, J. Geophys. Res., 113, D19202, doi:10.1029/2007JD009761, 2008.

Laakso, L., Merikanto, J., Vakkari, V., Laakso, H., Kulmala, M., Molefe, M., Kgabi, N., Mabaso, D., Carslaw, K. S., Spracklen, D. V., Lee, L. A., Reddington, C. L., and Kerminen, V.-M.: Boundary layer nucleation as a source of new CCN in savannah environment, Atmos. Chem. Phys., 13, 1957-1972, doi:10.5194/acp-13-1957-2013, 2013.

Laaksonen, A., Hamed, A., Joutsensaari, J., Hiltunen, L., Cavalli, F., Junkermann, W., Asmi, A., Fuzzi, S., and Facchini, M. C.: Cloud condensation nucleus production from nucleation events at a highly polluted region, Geophys. Res. Lett., 32, L06812, doi:10.1029/2004GL022092, 2005.

Lance, S., Medina, J., Smith, J. N., and Nenes, A.: Mapping the operation of the DMT Continuous Flow CCN counter, Aerosol Sci. Tech., 40, 242-254, 2006.

Leng, C. P., Cheng, T. T., Chen, J. M., Zhang, R. J., Tao, J., Huang, G. H., Zha, S. P., Zhang, M. G., Fang, W., Li, X., and Li, L.: Measssurements of surface cloud condensation nuclei and aerosol activity in downtown Shanghai, Atmos. Environ., 69, 354-361, 2013.

Lihavainen, H., Kerminen, V. M., Komppula, M., Hatakka, J., Aaltonen, V., Kulmala, M., and Viisanen, Y.: Production of "potential" cloud condensation nuclei associated with atmospheric new particle formation in north Finland, J. Geophys. Res., 108, 4872, doi:10.1029/2003JD003887, 2003.

Lohmann, U. and Feichter, J.: Global indirect aerosol effects: a review, Atmos. Chem. Phys., 5, 715-737, doi:10.5194/acp-5-7152005, 2005.

McMurry, P. H., Takano, H., and Anderson, G. R.: Study of the ammonia (gas)-sulphuric acid (aerosol) reaction rate, Environ. Sci. Technol., 17, 347-352, 1983.

McMurry, P. H., Fink, M., Sakurai, H., Stolzenburg, M. R., Mauldin, R. L., Smith, J., Eisele, F., Moore, K., Sjostedt, S., Tanner, D., Huey, L. G., Nowak, J. B., Edgerton, E., and Voisin, D.: A criterion for new particle formation in the sulfurrich Atlanta atmosphere, J. Geophys. Res., 110, D22S02, doi:10.1029/2005JD005907, 2005. 
Merikanto, J., Spracklen, D. V., Mann, G. W., Pickering, S. J., and Carslaw, K. S.: Impact of nucleation on global CCN, Atmos. Chem. Phys., 9, 8601-8616, doi:10.5194/acp-9-8601-2009, 2009.

Metzger, A., Verheggen, B., Dommen, J., Duplissy, J., Prevot, A. S., Weingartner, E., Riipinen, I., Kulmala, M., Spracklen, D. V., Carslaw, K. S., and Baltensperger, U.: Evidence for the role of organic in aerosol particle formation under atmospheric conditions, P. Natl. Acad. Sci. USA, 107, 6646-6651, 2010.

Mönkkönen, P., Koponen, I. K., Lehtinen, K. E. J., Hämeri, K., Uma, R., and Kulmala, M.: Measurements in a highly polluted Asian mega city: observations of aerosol number size distribution, modal parameters and nucleation events, Atmos. Chem. Phys., 5, 57-66, doi:10.5194/acp-5-57-2005, 2005.

Nieminen, T., Manninen, H. E., Sihto, S. L., Yli-Juuti, T., Mauldin, R. L., Petaja, T., Riipinen, I., Kerminen, V. M., and Kulmala, M.: Connection of sulfuric acid to atmospheric nucleation in boreal forest, Environ. Sci. Technol., 43, 4715-4721, 2009.

O'Dowd, C. D.: Biogenic coastal aerosol production and its influence on aerosol radiative properties, J. Geophys. Res., 106, 1545-1549, 2001.

O’Dowd, C. D., Aalto, P., Hameri, K., Kulmala, M., and Hoffmann, T.: Atmospheric particles from organic vapors, Nature, 416, 497-498, 2002.

Olofson, K. F. G., Andersson, P. U., Hallquist, M., Ljungström, E., Tang, L., Chen, D., and Pettersson, J. B. C.: Urban aerosol formation in the Arctic boundary layer, J. Geophys. Res., 103, 83098321, 2009.

Paasonen, P., Nieminen, T., Asmi, E., Manninen, H. E., Petäjä, T., Plass-Dülmer, C., Flentje, H., Birmili, W., Wiedensohler, A., Hõrrak, U., Metzger, A., Hamed, A., Laaksonen, A., Facchini, M. C., Kerminen, V.-M., and Kulmala, M.: On the roles of sulphuric acid and low-volatility organic vapours in the initial steps of atmospheric new particle formation, Atmos. Chem. Phys., 10, 11223-11242, doi:10.5194/acp-10-11223-2010, 2010.

Petäjä, T., Mauldin, III, R. L., Kosciuch, E., McGrath, J., Nieminen, T., Paasonen, P., Boy, M., Adamov, A., Kotiaho, T., and Kulmala, M.: Sulfuric acid and $\mathrm{OH}$ concentrations in a boreal forest site, Atmos. Chem. Phys., 9, 7435-7448, doi:10.5194/acp9-7435-2009, 2009.

Petters, M. D. and Kreidenweis, S. M.: A single parameter representation of hygroscopic growth and cloud condensation nucleus activity, Atmos. Chem. Phys., 7, 1961-1971, doi:10.5194/acp-71961-2007, 2007.

Petzold, A., Kopp, C., and Niessner, R.: The dependence of the specific attenuation cross-section on black carbon mass fraction and particle size, Atmos. Environ., 31, 661-672, 1997.

Pierce, J. R. and Adams, P. J.: Efficiency of cloud condensation nuclei formation from ultrafine particles, Atmos. Chem. Phys., 7, 1367-1379, doi:10.5194/acp-7-1367-2007, 2007.

Pierce, J. R. and Adams, P. J.: Uncertainty in global CCN concentrations from uncertain aerosol nucleation and primary emission rates, Atmos. Chem. Phys., 9, 1339-1356, doi:10.5194/acp-91339-2009, 2009.

Ramanathan, V., Crutzen, P. J., Kiehl, J. T., and Rosenfeld, D.: Aerosols, climate, and the hydrological cycle, Science, 294, 2119-2124, 2001.

Riipinen, I., Pierce, J. R., Yli-Juuti, T., Nieminen, T., Häkkinen, S., Ehn, M., Junninen, H., Lehtipalo, K., Petäjä, T., Slowik, J.,
Chang, R., Shantz, N. C., Abbatt, J., Leaitch, W. R., Kerminen, V.-M., Worsnop, D. R., Pandis, S. N., Donahue, N. M., and Kulmala, M.: Organic condensation: a vital link connecting aerosol formation to cloud condensation nuclei (CCN) concentrations, Atmos. Chem. Phys., 11, 3865-3878, doi:10.5194/acp11-3865-2011, 2011.

Roberts, G. C. and Nenes, A.: A continuous-flow streamwise thermal-gradient $\mathrm{CCN}$ chamber for atmospheric measurements, Aerosol Sci. Tech., 39, 206-221, 2006.

Sakurai, T., Fujita, S. I., Hayami, H., and Furuhashi, N.: A study of atmospheric ammonia by means of modeling analysis in the Kanto region of Japan, Atmos. Environ., 39, 203-210, 2005.

Shen, X. J., Sun, J. Y., Zhang, Y. M., Wehner, B., Nowak, A., Tuch, T., Zhang, X. C., Wang, T. T., Zhou, H. G., Zhang, X. L., Dong, F., Birmili, W., and Wiedensohler, A.: First long-term study of particle number size distributions and new particle formation events of regional aerosol in the North China Plain, Atmos. Chem. Phys., 11, 1565-1580, doi:10.5194/acp-11-15652011, 2011.

Shi, J. P., Evans, D. E., Khan, A. A., and Harrison, R. M.: Sources and concentrations of nanoparticles $(10 \mathrm{~nm}$ in diameter) in the urban atmosphere, Atmos. Environ., 35, 1193-1202, 2001.

Smith, J. N., Moore, K. F., McMurry, P. H., and Eisele, F. L.: Atmospheric measurements of sub-20 nm diameter particle chemical composition by thermal desorption chemical ionization mass spectrometry, Aerosol Sci. Tech., 38, 100-110, 2004.

Spracklen, D. V., Carslaw, K. S., Kulmala, M., Kerminen, V.-M., Mann, G. W., and Sihto, S.-L.: The contribution of boundary layer nucleation events to total particle concentrations on regional and global scales, Atmos. Chem. Phys., 6, 5631-5648, doi:10.5194/acp-6-5631-2006, 2006.

Spracklen, D. V., Carslaw, K. S., Kulmala, M., Kerminen, V. M., Sihto, S. L., Riipinen, I., Merikanto, J., Mann, G. W., Chipperfield, M. P., Wiedensohler, A., Birmili, W., and Lihavainen, H.: Contribution of particle formation to global cloud condensation nuclei concentrations, Geophys. Res. Lett., 35, L06808, doi:10.1029/2007GL033038, 2008.

Vakkari, V., Laakso, H., Kulmala, M., Laaksonen, A., Mabaso, D., Molefe, M., Kgabi, N., and Laakso, L.: New particle formation events in semi-clean South African savannah, Atmos. Chem. Phys., 11, 3333-3346, doi:10.5194/acp-11-3333-2011, 2011.

Vehkamäki, H., Dal Maso, M., Hussein, T., Flannagan, R., Hyvärinen, A., Lauros, J., Merikanto, J., Mönkkönen, P., Pihlatie, M., Salminen, K., Sogacheva, L., Thum, T., Ruuskanen, T. M., Keronen, P., Aalto, P. P., Hari, P., Lehtinen, K. E. J., Rannik, Ü., and Kulmala, M.: Atmospheric particle formation events at Värriö measurement station in Finnish Lapland 1998-2002, Atmos. Chem. Phys., 4, 2015-2023, doi:10.5194/acp-4-2015-2004, 2004.

Vuollekoski, H., Kerminen, V. M., Anttila, T., Sihto, S. L., Vana, M., Ehn, M., Korhonen, H., McFiggans, G., O’Dowd, C. D., and Kulmala, M.: Iodine dioxide nucleation simulations in coastal and remote marine environments, J. Geophys. Res., 114, D00206, doi:10.1029/2008JD010713, 2009.

Wang, Y., Zhuang, G. S., Zhang, X. Y., Huang, K., Xu, C., Tang, A. H., Chen, J. M., and An, Z. S.: The ion chemistry, seasonal cycle, and sources of $\mathrm{PM}_{2.5}$ TSP aerosol in Shanghai, Atmos. Environ., 40, 2935-2952, 2006. 
Wang, X. F., Zhang, Y. P., Chen, H., Yang, X., and Chen, J. M.: Particle nitrate formation in a highly polluted urban area: a case study by single-particle mass spectrometry in Shanghai, Environ. Sci. Technol., 43, 3061-3066, 2009.

Wang, Z. B., Hu, M., Sun, J. Y., Wu, Z. J., Yue, D. L., Shen, X. J., Zhang, Y. M., Pei, X. Y., Cheng, Y. F., and Wiedensohler, A.: Characteristics of regional new particle formation in urban and regional background environments in the North China Plain, Atmos. Chem. Phys., 13, 12495-12506, doi:10.5194/acp-13-124952013, 2013.

Wang, Z. B., Hu, M., Wu, Z. J., and Yue, D. L., Reaserch on the formation mechanism of new particles in the atmosphere, Acta Chim. Sinica, 71, 519-527, 2013.

Weber, R. J., Marti, J. J., McMurry, P. H., Eisele, F. L., Tanner, D. J., and Jefferson, A.: Measured atmospheric new particle formation rates: implications for nucleation mechanisms, Chem. Eng. Commun., 151, 53-64, 1996.

Weber, R. J., McMurry, P. H., Mauldin, R. L., Tanner, D. J., Eisele, F. L., Clarke, A. D., and Kapustin, V. N.: New particle formation in the remote troposphere: a comparison of observations at various sites, Geophys. Res. Lett., 26, 307-310, doi:10.1029/1998GL900308, 1999.

Weingartner, E., Saathoff, H., Schnaiter, M., Streit, N., Bitnar, B., and Baltensperger, U.: Absorption of light by soot particles: determination of the absorption coefficient by means of aethalometers, J. Aerosol Sci., 34, 1445-1463, 2003.

Wiedensohler, A., Cheng, Y. F., Nowak, A., Wehner. B., Achtert, P., Berghof, M., Birmili, W., Wu, Z. J., Hu, M., Zhu, T., Takegawa, N., Kita, K., Kondo, Y., Lou, S. R., Hofzumahaus, A., Holland, F., Wahner, A., Gunthe, S. S., Rose, D., Su, H., and Pöschl, U.: Rapid aerosol growth and increase of cloud condensation nucleus activity by secondary aerosol formation and condensation: a case study for regional air pollution in northeastern China, Geophys. Res. Lett., 114, D00G08, doi:10.1029/2008JD010884, 2009.

Wu, Z., Hu, M., Liu, S., Wehner, B., Bauer, S., Mäßling, A., Wiedensohler, A., Petäjä, T., Dal Maso, M., and Kulmala, M.: New particle formation in Beijing, China: statistical analysis of a 1-year dataset, J. Geophys. Res., 112, D09209, doi:10.1029/2006JD007406, 2007.
Wu, Z. J., Hu, M., Lin, P., Liu, S., Wehner, B., and Wiedensohler, A.: Particle number size distribution in the urban atmosphere of Beijing, China, Atmos. Environ., 42, 7967-7980, doi:10.1016/j.atmosenv.2008.06.022, 2008.

Yu, F. Q.: Effect of ammonia on new particle formation: a kinetic $\mathrm{H}_{2} \mathrm{SO}_{4}-\mathrm{H}_{2} \mathrm{O}-\mathrm{NH}_{3}$ nucleation model constrained by laboratory measurements, J. Geophys. Res., 111, D01204, doi:10.1029/2005JD005968, 2006.

Yu, F., Wang, Z., Luo, G., and Turco, R.: Ion-mediated nucleation as an important global source of tropospheric aerosols, Atmos. Chem. Phys., 8, 2537-2554, doi:10.5194/acp-8-2537-2008, 2008.

Yu, H., McGraw, R., and Lee, S. H.: Effects of amines on formation of sub-3 nm particles and their subsequent growth, Geophys. Res. Lett., 39, L02807, doi:10.1029/2011GL050099, 2012.

Yue, D. L., Hu, M., Zhang, R. J., Wu, Z. J., Su, H., Wang, Z. B., Peng, J. F., He, L. Y., Huang, X. F., Gong, Y. G., and Wiedensohler, A.: Potential contribution of new particle formation to cloud condensation nuclei in Beijing, Atmos. Environ., 45, 6070-6077, 2011.

Zhang, R., Jing, J., Tao, J., Hsu, S.-C., Wang, G., Cao, J., Lee, C. S. L., Zhu, L., Chen, Z., Zhao, Y., and Shen, Z.: Chemical characterization and source apportionment of $\mathrm{PM}_{2.5}$ in Beijing: seasonal perspective, Atmos. Chem. Phys., 13, 7053-7074, doi:10.5194/acp-13-7053-2013, 2013.

Zhang, R. Y.: Getting to the critical nucleus of aerosol formation, Science, 328, 1366-1367, 2010.

Zhang, R. Y., Khalizov, A., Wang, L., Hu, M., and Xu, W.: Nucleation and growth of nanoparticles in the atmosphere, Chem. Rev., 112, 1957-2011, 2012.

Zheng, J., Hu, M., Zhang, R., Yue, D., Wang, Z., Guo, S., Li, X., Bohn, B., Shao, M., He, L., Huang, X., Wiedensohler, A., and Zhu, T.: Measurements of gaseous $\mathrm{H}_{2} \mathrm{SO}_{4}$ by AP-ID-CIMS during CAREBeijing 2008 Campaign, Atmos. Chem. Phys., 11, 7755-7765, doi:10.5194/acp-11-7755-2011, 2011. 